\title{
Development of Treatment Strategies to Combat EHF (Ebola Hemorrhagic Fever): Possible Sites of Actions and Targets for Anti-Ebola Drug Discovery
}

\author{
Md Shariful Islam ${ }^{1 *}$, Md Salahuddin² ${ }^{2}$ AKM Mohiuddin ${ }^{1}$ and Abu Zaffar Shibly ${ }^{1}$ \\ ${ }^{1}$ Department of Biotechnology and Genetic Engineering, Mawlana Bhashani Science and Technology University, Santosh, Tangail-1902, Bangladesh \\ ${ }^{2}$ Faculty of Medicine, University of Hongkong, Hong Kong
}

Submission: March 28, 2017; Published: May 30, 2017

"Corresponding author: Department of Biotechnology and Genetic Engineering, Mawlana Bhashani Science and Technology University, Santosh Tangail 1902, Bangladesh, Email: sharifbge@gmail.com

\begin{abstract}
Ebola Hemorrhagic Fever (EHF) has become a public health emergency of international concern which is linear, single stranded, negative strain RNA molecule and has a virally encoded glycoprotein (GP) which was found Zaire in Congo. It is known as zoonotic virus and causes significant morbidity and mortality in primates. Filovirus is transmitted via direct contact with bodily fluids or blood. Treatment of Ebola is not well developed and does not have a possible approved vaccine till now though there are various types of ongoing clinical trials research has been worked out. Since from previous research it shows us that, filovirus is currently now recognized a dangerous threat to the world. Our main objective of this editorial is to highlight the specific targeted mechanism of actions development for the discovery of anti-Ebola vaccines for the development of treatment strategies to combat Ebola Hemorrhagic Fever
\end{abstract}

Keywords: Ebola hemorrhagic fever; Glycoprotein; Zoonotic virus; Anti-Ebola drug; Primates; Zaire; Biological weapon

\section{Mini Review}

Against Ebola virus currently researchers does not find any specific vaccine. By understanding of the pathophysiology and transfer of the outbreak, it is crucial for identifying the primary agent of this disease. In most studies it was found Ebola is spread out by handling of infected of animals. In these recent cases, the very 1 st source of this filovirus was identified animals which is found dead or hunted in the forest area, followed by personto-person contact [1]. At present, the outbreak of filoivirus in Guinea and West African is now urgently an international alarming condition to the world.

Till now, Researchers are unable to discover any effective anti-Ebola drug discovery against Ebola and available strategy or any possible targeted response in the host as preliminary stages of treatment [2]. Recent findings stated the integration of the endothelial barrier determine the sepsis condition. Recently Liu and his colleagues worked on mouse model and results over expression due to a mutation in the endothelial area [3]. It has been reported that, glycoprotein of the zoonotic virus performed therapeutic and protective activity on mouse model [4-6].

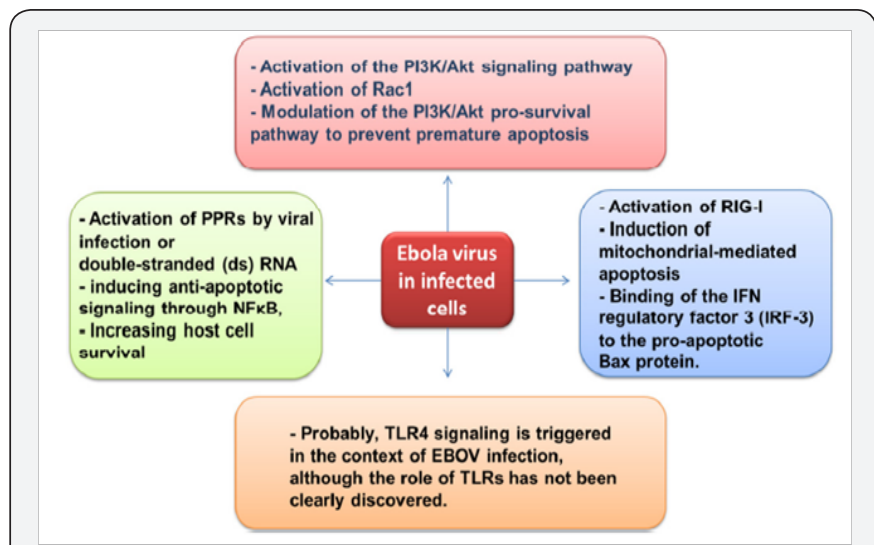

Figure 1: Signaling process of zoonotic virus [8].

From recent research findings it can conclude that, a structural change in the host cell namely CPE was observed in the inner surface of the blood vessels that are responsible for the loss of integration of blood vessel [7]. Moreover, investigations of Ebola found that they destroy the infected host cell and also 
perform cell death. In the meantime, activation of the Rac1 and the modulation of the PI3K/Akt pathway are performed to prevent premature apoptosis by this mode of action. Signaling process of zoonotic virus was shown in Figure 1. On the other hand the arresting cycle of this virus life cycle was shown in Figure 2 where the four sites of action has been identified namely prevention of attachment, fusion and possible arresting budding complex $[8,9]$. Scientists reports that, glycoprotein plays various types of roles includes a role in cytotoxicity and permeabilization activity [10].

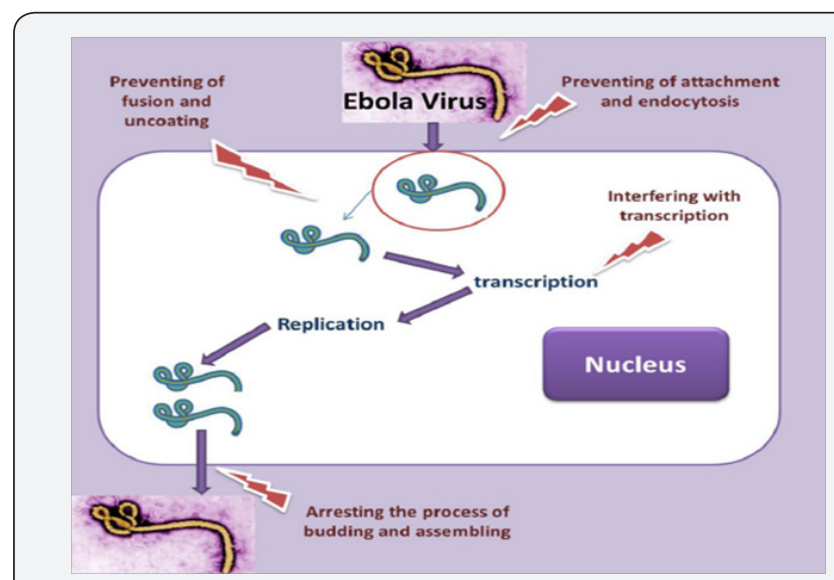

Figure 2: Mechanism of action of zoonotic virus life cycle in specific targeted approach [8].

In Liberia a breakthrough findings in clinical trial shows that, a French woman was received a favipiravir drugs where three experimental drugs was used for the treatment of that patient. Moreover, some exclusive drugs are now in clinically showed positive response against Ebola infection. Some of them include BCX4430, brincidofovir and lamivudine which have found very effective results in the discovery of anti-Ebola drugs [11-13].

\section{Summary}

In summary, Since Ebola is known as a threat to the world it is essential for more research in clinical trials. Recent literature reviews, there are many candidate vaccines that have introduced very positive results on primates and are strongly protected by the zoonotic virus. Many of these potential cures may become a future vaccine to help save the lives of those who have fallen victim to the deadly illness. With the persistence and drive of the researchers that continue to be hard at work in search for a vaccine, in future we are hopeful one day able to eliminate the fear of epidemic EBOV outbreaks, and save many innocent lives from being taken by the deadly Ebola virus.

\section{References}

1. Leroy EM, Rouquet $P$, Formenty $P$, Souquière $S$, Kilbourne A, et al. (2004) Multiple Ebola virus transmission events and rapid decline of central African wildlife. Science 303(5656): 387-390.

2. Wong G, Qiu X, Olinger GG, Kobinger GP (2014) Post-exposure therapy of filovirus infections. Trends 22(8): 456-463.

3. Xu H, Ye X, Steinberg H, Liu SF (2010) Selective blockade of endothelial NF-kB pathway differentially affects systemic inflammation and multiple organ dysfunction and injury in septic mice. J Pathol 220: 490-498.

4. Baize S, Pannetier D, Oestereich L, Rieger T, Koivogui L, et al. (2014) Emergence of Zaire Ebola virus disease in Guinea- preliminary report. N Engl J Med 371(15): 1418-1425.

5. Gupta M, Mahanty S, Bray M, Ahmed R, Rollin PE, et al. (2001) Passive transfer of antibodies protects immuno competent and imunodeficient mice against lethal Ebola virus infection without complete inhibition of viral replication. Journal of Virology 75: 4649-4654.

6. Oswald WB, Geisbert TW, Davis KJ, Geisbert JB, Sullivan NJ, et al. (2007) Neutralizing antibody fails to impact the course of Ebola virus infection in monkeys. PLoS Pathogens 3: 9.

7. Sullivan N, Yang ZY, Nabel GJ (2003) Ebola virus pathogenesis: implications for vaccines and therapies. JVirol 77: 9733-9737.

8. Saeidnia, Abdollahi (2014) Ebola hemorrhagic fever: current outbreak and progress in finding a cure. DARU Journal of Pharmaceutical Sciences 22: 70 .

9. Kaminskyy V, zhivotovsky B (2010) To kill or be killed: how viruses interact with the cell death machinery. J Intern Med 267: 473-482.

10. Sullivan NJ, Peterson M, Yang ZY, Kong WP, Duckers H, et al. (2005) Ebola virus glycoprotein toxicity is mediated by a dynamin-dependent protein-trafficking pathway. J Virol 79: 547-553.

11. Oestereich L, Lüdtke A, Wurr S, Rieger T, Muñoz-Fontela C, et al. (2014) Successful treatment of advanced Ebola virus infection with T-705 (favipiravir) in a small animal model. Antiviral Res 105: 17-21.

12. http://www.wncn.com/story/26569197/

13. http://www.msn.com/en gb/news/world/french-nurse-cured-ofebola-contracted-in-liberia/ar- BB7r1UJ

\section{Your next submission with Juniper Publishers will reach you the below assets}

- Quality Editorial service

- Swift Peer Review

- Reprints availability

- E-prints Service

- Manuscript Podcast for convenient understanding

- Global attainment for your research

- Manuscript accessibility in different formats

( Pdf, E-pub, Full Text, Audio)

- Unceasing customer service

Track the below URL for one-step submission https://juniperpublishers.com/online-submission.php 